MANdel MikLós ${ }^{1}$

\title{
VISSZAEMLÉKEZÉS AZ 1946-BAN ÚTJÁRA INDULT Magyar, 1948-Tól Magyar MarX Károly, A RENDSZERVÁLTÁs UTÁN BUdAPESTI KözGAZDA- SÁGTUDOMÁNYI ÉS ÁlLAMIGAZGATÁSI, 2004-TőL BudApesti Corvinus Egyetemre²
}

A XX. század második felére kibontakozó, az ezredforduló évtizedeire leépülö kétpólusú világgazdaság (gyakran ellentétes irányú) elvárásaihoz idomuló közgazdaság-tudomány felsőoktatási szintü müködtetésére szervezödö intézmény Magyar Közgazdaságtudományi Egyetem néven - 1948 szeptemberében kezdte meg felsőoktatási tevékenységböl fakadó müködését. A történelmi léptékü (rövid idötartamon belül is) gyakorta ismétlödö „rendszerváltásokban” gazdag, a „pesti Közgáz" néven elhíresült intézmény 1948 öszi megnyitásának hetvenedik évfordulójára irányuló visszaemlékezés megfogalmazására: az 1948 őszén megalakult egyetem első félévére beiratkozó Simai Mihály évfolyamtársam, aki többek között az egyetem megalakulását követö hét évtized során folyamatosan kibocsájtott diplomával rendelkezö, végzett közgazdászhallgatók által alapitott Közgáz Alma Máter néven bejegyzett (Soros György pénzügyi támogatását sajnálatosan nélkülözö) civil szervezet Elnökének baráti kérésére vállalkoztam.

A „pesti Közgáz” (XX. század második felét követő ezredforduló évtizedeit lefedő) közel háromnegyed évszázadot átívelő története a Magyar Közgazdaságtudományi Egyetem 1948 szeptemberére időzített megindítására vezethető vissza. A történelmi fordulat (konkrétabban az előkészítés alatt álló fordulat éve alatt) előhírnökeként megalakult intézmény hallgató-állománya és tanári kara több részből tevődött össze: egyrészt az 1857-ben politechnikumi rangot kapott Magyar Királyi József Műegyetem közgazdasági szakképzéssel összevont, 1934-ben megalakult József Nádor Müszaki és Közgazdaságtudományi Egyetem közgazdasági karán kiemelt szaktudású (statisztika, könyvvitel, kereskedelmi számtan stb.) tanszékvezető professzorok átvétele; továbbá az egyetem Közgazdasági karának (közgazdasági és közigazgatási osztály) első évfolyamos hallgatóinak átvétele is megtörtént, akik az új egyetem 2., 3. és 4. évfolyamán folytathatták tanulmányaikat; az új egyetem oktatásának centrumában (Marx „Tőke” feldolgozásán nyugvó) a politikai gazdaságtan oktatása állt, amely kiegészült a tervgazdaság, gazdaságtörténelem, gazdaságföldrajz, nemzetközi gazdaság és politikai ismeretek, a külön-

1 Vasdiplomás közgazdász

2 DOI: 10.14267/RETP2018.02.13 
böző ágazatok (ipar, mezőgazdaság, kereskedelem stb.) gazdaságtani berendezéseinek oktatásával. Az egyetemi státuszban oktató professzorokon kívül a meghatározó tárgyak oktatására a politikai, társadalmi, oktatási élet vezetőinek meghívására került sor; az új egyetemre felvett, frissen érettségizett első éves hallgatók mellett voltak volt hadifoglyok, menekültek, korábban érettségizettek, hazatért kommunisták hozzátartozói, Szlovákiából, Romániából, Kárpátaljáról kitelepítettek stb. Ebből a konglomerátumból került ki a „Közgáz nemzedék”, amelyik az ötvenes években a tervgazdálkodás káderállományának gerincét alkotta. Voltak már akkor is külföldi hallgatók a „fejlődő országokból” is.

Az új egyetem megnyitását követő évben a hazai sztálinizmusra jellemző törvénytelenség, az „össznépi” gyanakvásoktól telített közélet az új egyetem falai közé is „begyürüzött”. „A sorainkba beférkőzött ellenség felkutatása” az egyetemi hallgatók sorait sem kerülte el. A normál egyetemeken érvényesülő „követelmény szelekciót” az „osztályharc fokozódik" logikáját követő tisztogató akció helyettesítette. Ennek keretében a tanulmányi idő alatt homályban maradt, hogy ki számít „ellenséges elem”-nek, a diploma átvétele előtt viszont sor került az illető kizárására az ország valamennyi egyeteméről. A politikai skizofrénia következtében a „népi demokrácia ellensége” minősítést bárki politikai meggyőződésétől, nemzetiségétől, faji, vallási, társadalmi osztály származástól függetlenül - megszerezhette.

Egyetemünk első, 1948-1952-ben végzett évfolyamának tanulmányi ideje egybeesett a magyarországi Rákosi-rendszer legsötétebb éveivel. Joszif Visszarionovics 1953-ban bekövetkezett halála jelentős mértékben módosította a birodalom gyepüjén élők életkörülményeit. Néhány hónappal szakmai pályánk megkezdése után az 1953-as kormányprogram véget vetett a rendszer skizofrén, öncélú törvénytelenségekkel telített korszakának, és a poszt-sztálinista évtizedeket a viszonylag rövid időszakonként ismétlődő koncepció váltások és az azokhoz történő alkalmazkodás kényszere váltotta fel.

Néhány évvel megalakulása után a Közgáz felvette Marx Károly nevét, evvel is jelezve az 1950-51-es mélypontokhoz képest szellemi felépítést hozó enyhülést és a rövid ideig tartó Nagy Imre-korszakot. Nagy Imre több éven keresztül volt a Közgáz professzora, és kapcsolatát az egyetemmel 1956. november 4-éig megőrízte.

1956 után csaknem 200 hallgató távozott külföldre. Többségükből kiváló szakember, jómódú üzletember lett. Nem sokan hagyták el szakmájukat és kevesen tagadták meg egyetemüket. A 60-as évek közepén fokozatosan módosult az egyetemi oktatás. Elsősorban a magyar tervgazdálkodás kritikája erősödött fel. 1964-ben (a szocialista térségben elsőként) tanítottunk az Európai Közös Piacról, beleértve ebbe a termelő erők fejlődésében betöltött progresszív szerepét is.

Jelentős fordulatot hozott az ország és az egyetem életében az 1968-as év. A hallgatók - a kormányzat ellenzése ellenére - a korábbiaknál sokkal nagyobb szerepet kaptak az érdemi beleszólásra az egyetem ügyeibe. Az 1968-ban bevezetett gazdasági reform előkészítésében több tanárunk is részt vett.

Igen jelentős szerepe volt az 1968 utáni reformokban annak, hogy a 60-as évek végére már több mint 30 tanársegéd vagy adjunktus tölthetett 1-1 szemesztert vagy ennél hosszabb időt amerikai egyetemeken (nem a Soros, hanem) a Ford Alapítvány és az amerikai kutatási csereprogram keretében.

A piaci viszonyok hazai térhódítása, Magyarország aktív részvétele a piaci szabályokat érvényesítő GATT-ban, hazánk belépése a Világbankba és a Nemzetközi Valuta- 
alapba új fejezetett nyitott egyetemünk életében. A 80-as években létrejött a „Karl Marx Business School". A 80-as évek végén George Bush az Amerikai Egyesült Államok elnöke (még az egyetemünkön felállított) Marx Károly szobránál mondta el beszédét.

A rendszerváltás után a Közgáz tovább nem viselhette Marx Károly nevét. 2004-ben felvette (az Államigazgatási Főiskola integrálásával, illetve a Szent István Egyetemből kivált Kertészeti valamint Élelmiszeripari karokkal bővült) 6 karból összetevődő Budapesti Corvinus Egyetem nevet.

Ez az átszervezés a 2010 utáni Orbán vezette kormány „reformjai” miatt visszarendeződött. 